\title{
P-Selectin Mediates Adhesion of Platelets to Neuroblastoma and Small Cell Lung Cancer
}

\author{
Jennifer P. Stone * and Denisa D. Wagner** \\ Center for Hemostasis and Thrombosis Research, New England Medical Center and Tufts University, \\ Departments of * Medicine and ${ }^{\ddagger}$ Anatomy and Cellular Biology, Boston, Massachusetts 02111
}

\begin{abstract}
Activated platelets and stimulated endothelial cells express $\mathbf{P}$ selectin, an integral membrane protein receptor that binds monocytes and neutrophils. P-selectin mediates adhesion to glycoproteins with carbohydrate structures containing sialylLewis $\mathbf{X}$. Since many carcinoma cells also express these carbohydrate structures and are known to interact with platelets, we asked whether P-selectin may mediate this interaction. Both small cell lung cancer and neuroblastoma cell lines bound to activated platelets, and this interaction was blocked with inhibitory anti-P-selectin antibodies and by pretreatment of these cancer cells with neuraminidase or trypsin. Platelet binding to the small cell lung cancer cells was not inhibited with anti-GP IIb-IIIa antibody or Arg-Gly-Asp-Ser peptide. Pretreatment of the neuroblastoma cells with inhibitors of $\mathrm{N}$-linked carbohydrate biosynthesis had little effect on binding to P-selectin, indicating that relevant carbohydrate ligand(s) may be $O$-linked. In addition, lipospheres containing P-selectin specifically bound to cryostat sections derived from a small cell lung tumor and two neuroblastoma tumors, but not to sections of normal lung. These observations demonstrate that P-selectin mediates binding of platelets to small cell lung cancer and to neuroblastoma and suggest a possible role for this lectin in metastasis. $(J$. Clin. Invest. 1993. 92:804-813.) Key words: blood platelets • selectin • cell adhesion molecules $\bullet$ neoplasm metastasis • sialoglycoproteins
\end{abstract}

\section{Introduction}

Hematogenous tumor cell metastasis involves the arrest, attachment, and extravasation of tumor cells. Tumor cell spread is a complex, multistep process that is dependent on a number of cell-to-cell interactions. In this study we focus on the molecular aspects of the interaction between cancer cells and platelets. Several lines of investigation suggested that platelets facilitate blood-born metastasis (1-4). Gasic and colleagues (5) first noted that the number of experimentally induced pulmonary metastasis was reduced in mice when they were made thrombocytopenic before the injection of tumor cells and that the incidence of metastasis was positively correlated to the platelet count. Morphological observations of tumor cells arrested in capillaries have shown the cancer cells surrounded with acti-

Address correspondence to Dr. Denisa D. Wagner, New England Medical Center, Box 832, Hematology/Oncology, Boston, MA 02111.

Received for publication 11 June 1992 and in revised form 26 March 1993.

J. Clin. Invest.

(C) The American Society for Clinical Investigation, Inc.

0021-9738/93/08/0804/10 \$2.00

Volume 92, August 1993, 804-813 vated platelets. Electron micrographs demonstrate close contact between the platelet and the tumor cell (4). Although the integrin receptor GP IIb-IIIa $\left(\alpha_{\mathrm{Ib}} \beta_{3}\right)$ appears to mediate the interaction of platelets with some cancer cells (6-8), whether or not other molecules present on the activated platelet may also mediate binding to tumor cells is not known.

P-selectin (CD62, PADGEM, GMP140) $(9,10)$ is a member of the selectin family of adhesion receptors (11). The other two members are L-selectin, the peripheral lymph node lymphocyte homing receptor (murine Mel 14 antigen or human Leu8 antigen/LAM-1 ) (12), and E-selectin, an endothelial leukocyte adhesion molecule that is induced by cytokines (13). The selectins are structurally similar in that they contain an $\mathrm{NH}_{2}$-terminal lectin domain, followed by an epidermal growth factor domain, two to nine complement regulatory protein consensus repeat units, a transmembrane segment, and a short cytoplasmic tail (14-18).

P-selectin binds to neutrophils and monocytes (19-21), and therefore it is likely involved in inflammatory, wound healing, and immune responses. P-selectin is located in alpha granules of platelets $(22,23)$ and Weibel-Palade bodies of endothelial cells $(24,25)$. Upon platelet or endothelial cell activation with mediators such as thrombin, alpha granule and WeibelPalade body membranes fuse rapidly with the plasma membrane as the granules release their contents, leading to the expression of P-selectin on the cell surface. P-selectin mediates binding of these cells to carbohydrate structures containing the sialyl-Lewis $\mathrm{X}$ antigen (26-28). In contrast to E-selectin, which has overlapping carbohydrate specificity, the P-selectin ligand on monocytes and neutrophils is susceptible to protease treatment $(29,30)$.

The sialyl-Lewis $\mathrm{X}$ antigen that appears to be an important component of both the P-selectin and E-selectin ligands is expressed on phagocytic cells as well as on many types of tumor cells (31-33). A colon carcinoma cell line HT-29 was shown to bind to cytokine-activated endothelium and the binding was dependent on E-selectin (34-35). We have investigated whether P-selectin may also be implicated in cellular interaction with carcinoma cells, specifically if it mediates the observed adhesion of platelets to tumor cells.

\section{Methods}

Cells. Platelets from normal human donors were isolated by gel filtration from fresh anticoagulated blood with Ware's solution $(0.1 \mathrm{M}$ citrate buffer, $10 \mathrm{mM}$ acetylsalicylic acid) on a Sepharose 2B (Sigma Chemical Co., St. Louis, MO) column equilibrated with Pipes buffer. Activated platelets were prepared by the addition of $0.15 \mathrm{U}$ thrombin/ $\mathrm{ml}$ (Sigma Chemical Co.) and incubated at $22^{\circ} \mathrm{C}$ for $20 \mathrm{~min}$ without stirring. The platelets were used in cell adhesion assays within $30 \mathrm{~min}$ of preparation. The platelets isolated from a patient with Glanzmann's thrombasthenia fully characterized by Dr. John Erban (New England Medical Center, Boston, MA) were prepared in the same manner ex- 
cept the blood was anticoagulated with Ware's solution without acetylsalicylic acid and the platelets were placed over a column equilibrated with Hepes buffer. These platelets were used within $4-36 \mathrm{~h}$ from preparation.

HL60, a promyelocytic leukemia cell line, U937, a human histiocytic lymphoma, and Daudi cells obtained from American Type Culture Collection (ATCC), ${ }^{1}$ Rockville, MD, were maintained in culture as described by Larsen et al. (19). NCI-H128 cell line (ATCC), derived from malignant pleural fluid of a patient with small cell lung cancer of the lung, were grown in Iscove's modified Dulbecco's medium with $20 \%$ FCS. NCI-H345 cell line (ATCC) derived from bone marrow of one patient and NCI-H146 cell line (ATCC) derived from malignant pleural fluid of another patient with small cell lung cancer were grown in RPMI with $5 \%$ FCS and $15 \%$ FCS, respectively. Human neuroblastoma cells, NB5-A2 (A. S. Tischler, New England Medical Center, Boston, MA) derived from a cervical lymph node metastasis of an adrenal neuroblastoma were grown in RPMI with $10 \%$ horse serum and 5\% FCS. SK-N-SH cell line (ATCC) derived from a neuroblastoma tumor was grown in Eagle's MEM with 10\% FCS. CRL 1566 cell line (ATCC) derived from a mouse teratocarcinoma tumor was grown in DME with $10 \%$ FCS. A human colon carcinoma, HT 29, obtained from D. Jefferson (New England Medical Center, Boston, MA); human gastric adenocarcinoma, Hs746T; a human breast adenocarcinoma, MCF7; and murine melanoma $B_{16} F_{10}$, obtained from B.R. Zetter (Children's Hospital, Boston, MA), were grown in DME with $10 \%$ FCS. CRL 1803 cell line (ATCC) derived from a medullary thyroid carcinoma was grown in DME with $10 \%$ FCS. F9 cell line (ATCC) derived from a mouse embryonal carcinoma was also grown in DME with $10 \%$ FCS. All cell lines tested negative for mycoplasma.

For inhibition or modification of N-glycosylation of SK-N-SH cell line and endothelial cells, the cells were cultured in medium containing tunicamycin $(0.1-1.0 \mu \mathrm{g} / \mathrm{ml})$, deoxymannojirimycin $(100.0 \mu \mathrm{g} / \mathrm{ml})$, and swainsonine $(1.0 \mu \mathrm{g} / \mathrm{ml})$ for $30 \mathrm{~h}$.

Reagents. P-selectin was purified from outdated human platelets by immunoaffinity chromatography as described (30). Polyclonal anti-P-selectin antibodies were raised in rabbits using a standard immunization schedule by $\mathrm{E}$. Larsen. Monoclonal antibodies directed to $\mathrm{P}$ selectin comprised the noninhibitory antibody AC1.2 (19) and inhibitory monoclonal antibodies GE12 and GA6 (36). These antibodies are the same isotype, $\operatorname{IgG}_{1}$ kappa. The monoclonal antibody BR5 recognizes the propeptide of von Willebrand factor and is $\operatorname{IgG}_{2}$ kappa (37). Anti-GP IIb-IIIa (CDW41a; AMAC Inc., Westbrook, ME) is an IgG1 kappa, and we have verified that it inhibits platelet aggregation. CD15 (Amac, Inc., Westbrook, ME), CSLEX1 (ATCC), and 44812 (Lanny Hecker, New England Medical Center, Boston, MA) are IgM antibodies. $\mathbf{4 4 8 1 2}$ is a monoclonal antibody made using platelet alpha granules' membranes as an immunogen, and it served as a control IgM antibody for immunofluorescent staining and flow cytometric analysis of the tumor cells. Purified human IgG from serum, Arg-Gly-Asp-Ser (RGDS), EDTA, heparin, fucoidin, trypsin, soybean trypsin inhibitor (SBTI), 2,3-dehydro-2-deoxy- $N$-acetyl-neuramic acid, tunicamycin, deoxymannojirimycin, and swainsonine were purchased from Sigma Chemical Co. Vibrio cholerae neuraminidase was obtained from CalBiochem Corp., La Jolla, CA.

Cell adhesion assays. The rosetting, phase contrast cell adhesion assay was performed by the method of Larsen et al. (19), except aliquots of $40 \mu \mathrm{l}$ of the platelet and cell suspension were mixed and incubated together. When two or more platelets adhered to a single cell or a small cluster of cells composed of three cells or less, a positive score for adhesion was given. All experiments were performed on several days and in triplicate. Adherent cancer cell lines were suspended in RPMI with $1 \%$ FCS after a 4-min incubation at $37^{\circ} \mathrm{C}$ with $1 \mathrm{mM}$ EDTA in PBS. All cell lines, including the suspension cell lines (HL60, U937, NCI-H128, NCI-H345, and NCI-H146), were washed three times with

1. Abbreviations used in this paper: ATCC, American Type Culture Collection; RGDS, Arg-Gly-Asp-Ser; SBTI, soybean trypsin inhibitor.
RPMI containing $1 \%$ FCS before the assay. Antibody studies and studies with inhibitory or noninhibitory reagents were performed by preincubating $40 \mu \mathrm{l}$ of platelet suspension $\left(2 \times 10^{8} / \mathrm{ml}\right)$ with $40 \mu \mathrm{l}$ of reagent solution: EDTA (10 mM), RGDS (1 mM), heparin $(100 \mu \mathrm{g} / \mathrm{ml})$, or fucoidin $(100 \mu \mathrm{g} / \mathrm{ml})$ for $20 \mathrm{~min}$ at $22^{\circ} \mathrm{C}$. Then $40 \mu \mathrm{l}$ of cells $\left(3 \times 10^{6}\right.$ cells $/ \mathrm{ml}$ ) was added to the incubation mixture for $20 \mathrm{~min}$ at $22^{\circ} \mathrm{C}$. In the competitive inhibition experiments, $40 \mu$ l suspension of cells was preincubated with $40 \mu \mathrm{l}$ of purified P-selectin $(30 \mu \mathrm{g} / \mathrm{ml})$ for $20 \mathrm{~min}$. In other experiments a suspension of cancer cells was incubated with neuraminidase $(0.1 \mathrm{U} / \mathrm{ml})$ or trypsin $(10 \mu \mathrm{g} / \mathrm{ml})$ for 60 and $20 \mathrm{~min}$, respectively, at $37^{\circ} \mathrm{C}$, and then washed three times. The trypsinized cells were also incubated after the reaction with $\operatorname{SBTI}(500 \mu \mathrm{g} / \mathrm{ml})$ for 5 min. For controls in these experiments, a suspension of cancer cells was incubated in parallel either with neuraminidase $(0.1 \mathrm{U} / \mathrm{ml})$ and 2,3dehydro-2-deoxy- $N$-acetyl-neuramic acid $(0.2 \mathrm{mM})$ or trypsin $(10 \mu \mathrm{g} /$ $\mathrm{ml})$ and SBTI $(500 \mu \mathrm{g} / \mathrm{ml})$ for 60 and $20 \mathrm{~min}$, respectively, at $37^{\circ} \mathrm{C}$, and then washed three times. $40 \mu \mathrm{l}$ of these treated cells $\left(2 \times 10^{6} / \mathrm{ml}\right)$ was then incubated with $40 \mu \mathrm{l}$ of activated platelets for $20 \mathrm{~min}$.

Binding of tumor cell lines to phospholipid vesicles with and without $P$-selectin. P-selectin was incorporated into fluorescent, phospholipid vesicles as described (26). The binding of phospholipid vesicles with and without P-selectin to tumor cell lines was detected with a flow cytometer MDADS ( 541 ; Coulter Corp., Hialeah, FL). 5-10 $\mu$ l of fluorescent phospholipid vesicles with or without $P$-selectin were incubated with $25 \mu \mathrm{l}$ of a tumor cell line $\left(2 \times 10^{6} \mathrm{cells} / \mathrm{ml}\right)$ suspended in RPMI 1640 with $1 \%$ fetal calf serum and $5 \%$ BSA for $20 \mathrm{~min}$ at $22^{\circ} \mathrm{C}$. For the experiments with monoclonal antibodies, the phospholipid vesicles were incubated with the antibodies for $20 \mathrm{~min}$ before incubation with the cancer cells. Before analysis with flow cytometry, the sample was diluted 10 -fold with RPMI medium containing $1 \%$ FCS. The samples were identified by their forward and side light scatter profiles, and binding of phospholipid vesicles with and without P-selectin was quantitated by measuring fluorescence. Data were collected for 5,000 cells.

Adhesion studies of lipid-coated glass beads with and without $P$-selectin to cryostat sections of human tumors. The lipospheres (38) with and without P-selectin were prepared with cleaned and filtered $2-\mu \mathrm{m}$ glass beads (Duke Scientific Co., Palo Alto, CA). The beads suspended at $4 \times 10^{7}$ beads $/ \mathrm{ml}$ were mixed in a 3:1 ratio with either phospholipid vesicles alone or phospholipid containing purified $\mathrm{P}$-selectin. This mixture was sonicated for $3 \mathrm{~min}$ and incubated at $27^{\circ} \mathrm{C}$ for $30 \mathrm{~min}$ with frequent mixing. The lipid-coated beads were then washed three times in Tris-buffered saline with $0.1 \%$ BSA (Sigma Chemical Co.) to remove free vesicles.

The preparation of frozen sections and binding assay was adapted from modifications of the Stamper and Woodruff assay $(39,40)$. Small cell carcinoma with an intermediate size cellular component that was excised for a tissue diagnosis from an untreated patient's right upper lobe of lung was stored fresh, encased in OCT compound (an embedding medium for frozen tissue specimens) in liquid nitrogen in the New England Medical Center Organ Bank. Other tumor samples obtained from this organ bank included: a neuroblastoma tumor excised from an adrenal gland, a neuroblastoma tumor excised from the retroperitoneum, and squamous cell carcinoma excised from the lungs of two patients. (Permission and samples obtained through the organ bank's director, S. Naber). The lung of a patient with no prior respiratory disease was obtained at autopsy after the patient died of a medical illness. Cryostat sections ( $4 \mu \mathrm{m}$ thick) of these tissue samples were cut on an HM500 Zeiss Microtome at $-20^{\circ} \mathrm{C}$. Several sequential frozen sections were obtained and placed on glass slides and allowed to air dry for 30-60 min. The slides were stored unfixed at $4^{\circ} \mathrm{C}$ for $1-3 \mathrm{~d}$ or at $-80^{\circ} \mathrm{C}$ for up to $7 \mathrm{~d}$. Shortly before the assay $22-\mathrm{mm}^{2}$ wells around the sections were made. In each well $300 \mu 1$ of $10^{7}$ lipospheres/ml Tris-buffered saline with $2 \mathrm{mM} \mathrm{CaCl}_{2}, 2 \mathrm{mM} \mathrm{MgCl}, 4 \mathrm{mM} \mathrm{KCl}$, (Tris-buffered saline with cations), $1 \%$ FCS, and 5\% BSA were incubated and agitated on a gyratory shaker at $80-100 \mathrm{rpm}$ for $20 \mathrm{~min}$ at $4^{\circ} \mathrm{C}$. The unbound beads and solution were first removed from the wells by aspiration. Next, the slides were washed well by dipping in TBS with cations. Finally, a drop of gelvatol and a glass coverslip were placed on the 
section, and the sections were evaluated under phase and fluorescent microscopy. Sections flanking those studied in the binding assay and sections used for the original pathologic diagnosis were stained with hematoxylin and eosin.

\section{Results}

Tumor cell binding to platelets. Tumor cells known to have high metastatic potential in animal models or to aggregate platelets in vitro were initially screened for their ability to bind to platelets in a rosetting assay. In this assay, gel filtered platelets, which have been either activated with thrombin or maintained undisturbed in a resting state, were incubated with a suspension of tumor cells. An aliquot was then evaluated by light microscopy. The results presented in Table I show that human small cell lung cancer cell lines (NCI-H128 and NCI-H345), neuroblastoma cell lines (hNB5-A2 and SK-N-SH), and a mouse teratocarcinoma cell line (CRL 1566) bound to activated platelets and not to resting platelets. The binding of these tumor cells to activated platelets was inhibited with an inhibitory anti-P-selectin antibody indicating that the binding was

Table I. Rosetting of Platelets with Cancer Cell Lines

\begin{tabular}{|c|c|c|c|}
\hline \multirow[b]{2}{*}{ Cell line } & \multicolumn{3}{|c|}{ Percent adherence* } \\
\hline & $\begin{array}{l}\text { Resting } \\
\text { platelets }\end{array}$ & $\begin{array}{c}\text { Activated } \\
\text { platelets }\end{array}$ & $\begin{array}{c}\text { Activated } \\
\text { platelets: } \\
\text { anti-P-selectin } \\
\text { antibody, GE12 }\end{array}$ \\
\hline $\begin{array}{l}\text { U937 (Histiocytic } \\
\text { lymphoma) }\end{array}$ & $10.2 \pm 8.1$ & $73.8 \pm 9.2$ & $3.5 \pm 3.9$ \\
\hline $\begin{array}{l}\text { HL60 (Promyelocytic } \\
\text { leukemia) }\end{array}$ & $13.6 \pm 7.9$ & $82.0 \pm 11.5$ & $8.3 \pm 4.2$ \\
\hline $\begin{array}{l}\text { NCI-H128 (Small cell lung } \\
\text { cancer) }\end{array}$ & $8.1 \pm 4.1$ & $65.4 \pm 9.1$ & $7.7 \pm 4.7$ \\
\hline $\begin{array}{l}\text { NCI-H345 (Small cell lung } \\
\text { cancer) }\end{array}$ & $14.8 \pm 5.4$ & $69.7 \pm 8.2$ & $5.9 \pm 2.7$ \\
\hline $\begin{array}{l}\text { NCI-H146 (Small cell lung } \\
\text { cancer) }\end{array}$ & $3.2 \pm 1.1$ & $5.5 \pm 1.7$ & $7.6 \pm 0.5$ \\
\hline hNB5-A2 (Neuroblastoma) & $10.6 \pm 4.5$ & $58.2 \pm 24.2$ & $9.5 \pm 9.5$ \\
\hline SK-N-SH (Neuroblastoma) & $16.6 \pm 5.6$ & $64.4 \pm 5.4$ & $9.6 \pm 6.4$ \\
\hline $\begin{array}{l}\text { CRL } 1566 \\
\text { (Teratocarcinoma) }\end{array}$ & $11.3 \pm 3.6$ & $55.6 \pm 12.0$ & $6.5 \pm 3.0$ \\
\hline HT-29 (Colon carcinoma) & $11.6 \pm 3.1$ & $19.7 \pm 3.8$ & $8.0 \pm 2.2$ \\
\hline $\begin{array}{l}\text { CRL } 1803 \text { (Medullary } \\
\text { thyroid) }\end{array}$ & $6.6 \pm 4.4$ & $5.3 \pm 3.6$ & \\
\hline $\begin{array}{l}\text { Hs746T (Gastric } \\
\text { adenocarcinoma) }\end{array}$ & $4.0 \pm 2.1$ & $6.5 \pm 3.8$ & \\
\hline $\begin{array}{l}\text { MCF7 (Breast } \\
\text { adenocarcinoma) }\end{array}$ & $3.0 \pm 1.4$ & $3.9 \pm 1.8$ & \\
\hline F9 (Embryonal carcinoma) & $3.5 \pm 1.0$ & $6.0 \pm 1.0$ & \\
\hline $\mathrm{mMelB}_{16} \mathrm{~F}_{10}($ Melanoma $)$ & $4.6 \pm 1.7$ & $2.3 \pm 1.2$ & \\
\hline
\end{tabular}

* Mean percentage of cells with two or more platelets bound plus standard deviation was determined with the above cell lines: U937, HL60, promyelocytic leukemia; NCI-H128, small cell lung cancer (SCLC); NCI-H345 (SCLC); NCI-H146 (SCLC); hNB5-A2, neuroblastoma; SK-N-SH, neuroblastoma; CRL 1566, mouse teratocarcinoma; HT-29, colon carcinoma; CRL 1803, medullary thyroid carcinoma; Hs746T, gastric adenocarcinoma; MCF7, breast adenocarcinoma; F9, mouse embryonal carcinoma; and $\mathrm{mMelB}_{16} \mathrm{~F}_{10}$, mouse melanoma. mediated by P-selectin. Not all cell lines derived from small cell lung cancers ( NCI-H146) or amine precursor uptake decarboxylase tumors such as a medullary thyroid carcinoma (CRL 1803 ) bound in this assay to P-selectin expressed on activated platelets (Table I). The colon adenocarcinoma cell line (HT29) which binds to E-selectin $(34,35)$ did not strongly adhere to activated platelets compared with resting platelets ( Table I). Other cell lines derived from cancers such as human gastric adenocarcinoma (Hs746T), human breast adenocarcinoma (MCF7), mouse embryonal carcinoma (F9), and mouse melanoma $\left(\mathrm{mMelB}_{16} \mathrm{~F}_{10}\right)$ did not significantly bind to activated platelets (Table I). The myeloid cell lines HL60 and U937 which are known to bind to P-selectin on activated platelets (19) served as positive controls.

The role of P-selectin in binding of activated platelets to small cell lung cancer cells and neuroblastoma cells. The binding of activated platelets to neuroblastoma and small cell lung cancer cells was further investigated in the presence of specific reagents and after the cancer cells' surface had been enzymatically altered. Rosetting of activated platelets with small cell lung cancer cells did not occur in the presence of EDTA and was inhibited by heparin and fucoidin, sulfated glycans which are known to interfere with the binding of P-selectin to its ligand on neutrophils and HL60 cells (41) (Fig. $1 A$ ). Purified P-selectin $(30 \mu \mathrm{g} / \mathrm{ml})$ also inhibited the binding of activated platelets to small cell lung cancer cells, further implicating P-selectin as the adhesion receptor responsible for this interaction. The P-selectin ligand on neutrophils and monocytes is a sialylated glycoprotein(s). Pretreatment of the small cell lung cancer cells with neuraminidase or trypsin just before the rosetting assay completely abolished the binding of platelets (Fig. 1 $A$ ) indicating that the P-selectin ligand on these cells is also a sialylated glycoprotein. The use of neuraminidase and trypsin in the presence of their specific inhibitors, 2,3-dehydro-2deoxy- $N$-acetyl-neuramic acid and soybean trypsin inhibitor, respectively, did not disrupt the binding of activated platelets to the small cell lung cancer cells (Fig. $1 A$ ) demonstrating that these enzymes were acting through their designated activity and not through contaminating enzyme(s). The binding of activated platelets to the small cell lung cancer cell line, NCIH345, was similarly abolished when they were pretreated with either neuraminidase or trypsin (data not shown).

Similar to the two small cell lung cancer cell lines, NCIH128 and NCI-H345, the neuroblastoma cell line, SK-N-SH, also bound to activated platelets in a P-selectin-mediated interaction. The binding was inhibited by an inhibitory monoclonal antibody to P-selectin GE12 and not by the noninhibitory antibody $\mathrm{AC1} .2$ (Fig. $1 \mathrm{~B}$ ). In addition, pretreatment of these cells with neuraminidase or trypsin completely abolished the binding of platelets (Fig. $1 B$ ) indicating that the neuroblastoma cell line also binds to activated platelets through a sialylated glycoprotein.

Because the binding of cancer cells to platelets is in some instances mediated through integrins (6-8), we attempted to inhibit the binding of activated platelets with RGDS peptide (1.0 mM), or inhibitory antibodies to GP IIb-IIIa. Neither RGDS peptide nor antibodies to GP IIb-IIIa interfered with the binding of activated platelets to the small cell lung cancer cells (Fig. $1 A$ ). In addition, we have tested platelets obtained from a patient with Glanzmann's thrombasthenia (lacking functional GP IIb-IIIa, generously provided by Dr. John Erban, New England Medical Center) in the rosetting assay, and they bound to 
A

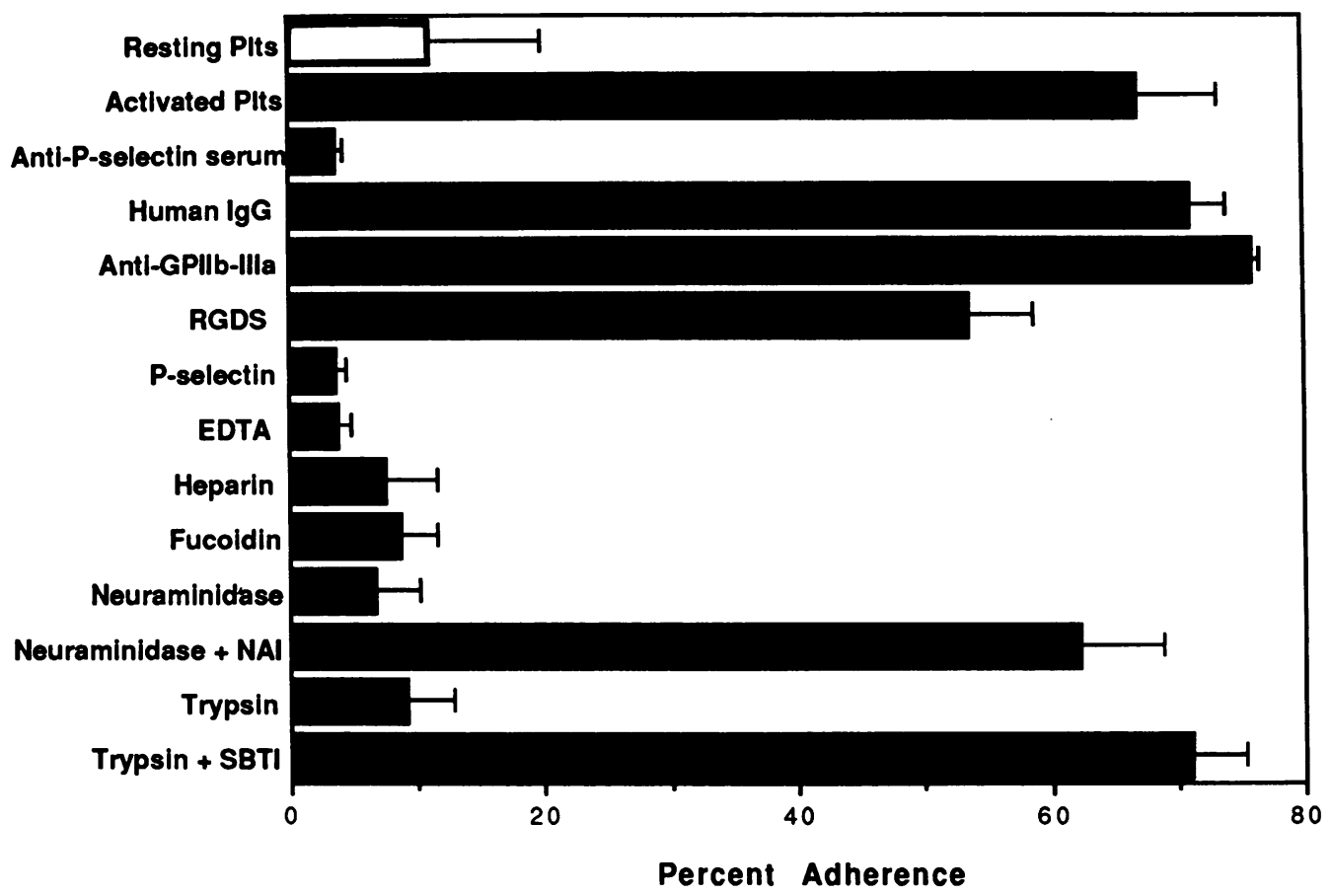

B

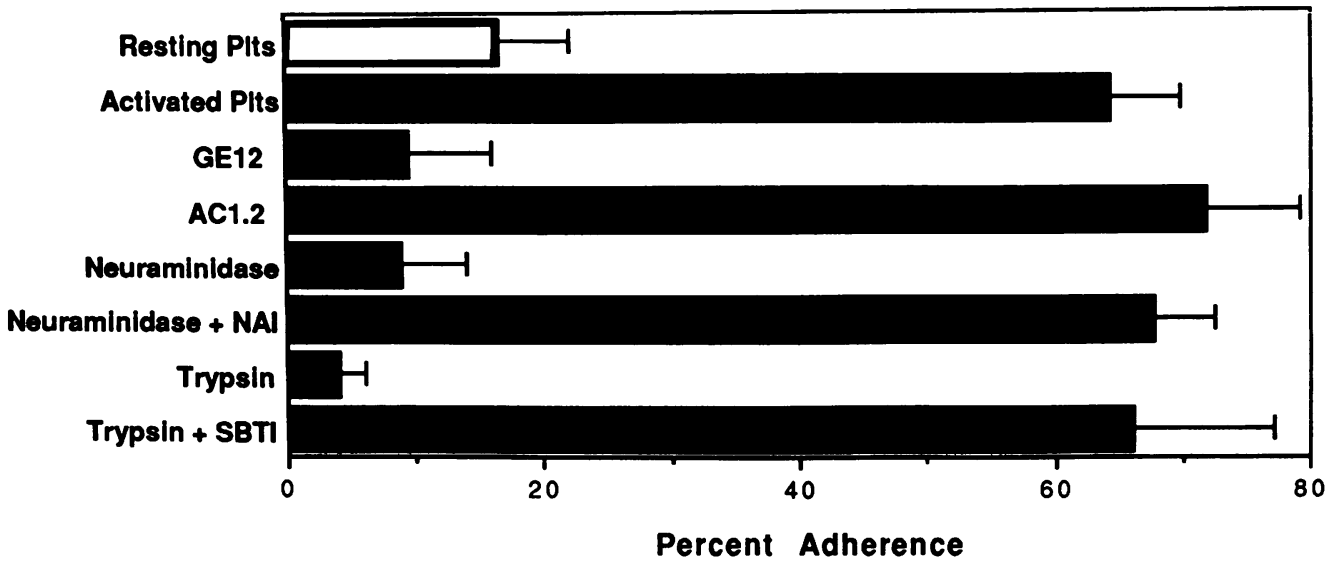

Figure 1. (A) Effect of different agents on the binding of activated platelets to small cell lung cancer cells ( NCIH128). The percentage of cells binding to two or more platelets was determined under phase microscopy. Resting platelets, open bar; activated platelets, solid bars. Antibodies include anti-Pselectin antiserum (1:3 dilution); hIgG, purified human IgG from serum $(20 \mu \mathrm{g} / \mathrm{ml})$; and anti-GP IIb-IIIa (33 $\mu \mathrm{g}$ / $\mathrm{ml})$. Other reagents include: RGDS, Arg-Gly-Asp-Ser ( 1 $\mathrm{mM}$ ), purified P-selectin (30 $\mu \mathrm{g} / \mathrm{ml}$ ), EDTA (10 mM), heparin $(100 \mu \mathrm{g} / \mathrm{ml})$, fucoi$\operatorname{din}(100 \mu \mathrm{g} / \mathrm{ml})$, neuraminidase $(0.1 \mathrm{U} / \mathrm{ml})$, the neuraminidase inhibitor ( $N A I)$, 2,3-dehydro-2-deoxy- $N$-acetyl-neuramic acid $(0.2 \mathrm{mM})$, trypsin $(10 \mu \mathrm{g} / \mathrm{ml})$, and SBTI $(500 \mu \mathrm{g} / \mathrm{ml})$. All agents tested that are known to inhibit platelet binding to myelocytes also inhibited platelet binding to the small cell lung cancer cells. Antibodies to GP IIb-IIIa and the RGDS peptide did not significantly effect the rosetting assay. The error bar represents one standard deviation. $(B)$ Effect of different agents on the binding of activated platelets to neuroblastoma cells (SK-N-SH). The rosetting cell adhesion assay was performed with the inhibitory antibody to P-selectin, GE12, as well as with the noninhibitory antibody, $\mathrm{AC1}$.2. The cell line SK-NSH was also pretreated with neuraminidase and trypsin as described in $A$. Resting platelets, open bar; activated platelets, solid bars. The error bar represents one standard deviation. the small cell lung cancer cells as well as to HL60 cells (Table II). This further confirms that GP IIb-IIIa does not mediate the binding of platelets to the small cell lung cancer cells, NCIH128.

Binding of P-selectin containing phospholipid vesicles to small cell lung cancer cells and neuroblastoma cells. To examine if P-selectin can bind to small cell lung cancer cells and neuroblastoma cells independent of other platelet components, we used flow cytometry to measure the adhesion of the cells to fluorescent phospholipid vesicles prepared with and without P-selectin. A shift in the intensity of cell fluorescence was seen in the small cell lung cancer cells (NCI-H128) incubated with the P-selectin containing phospholipid vesicles compared with the intensity of these cells incubated with phospholipid vesicles lacking P-selectin (Fig. 2). This shift in fluorescent intensity was specifically inhibited with inhibitory anti-P-selectin monoclonal antibodies (Fig. $2 c$ ) and not inhibited with an irrelevant, noninhibitory antibody (Fig. $2 d$ ). Similar results were obtained with the small cell lung cancer cells, NCI-H345 (not shown). The small cell lung cancer cell line, NCI-H146, which did not bind in the rosetting assay (Table I), did contain a small population of cells which had a shift in the fluorescent 


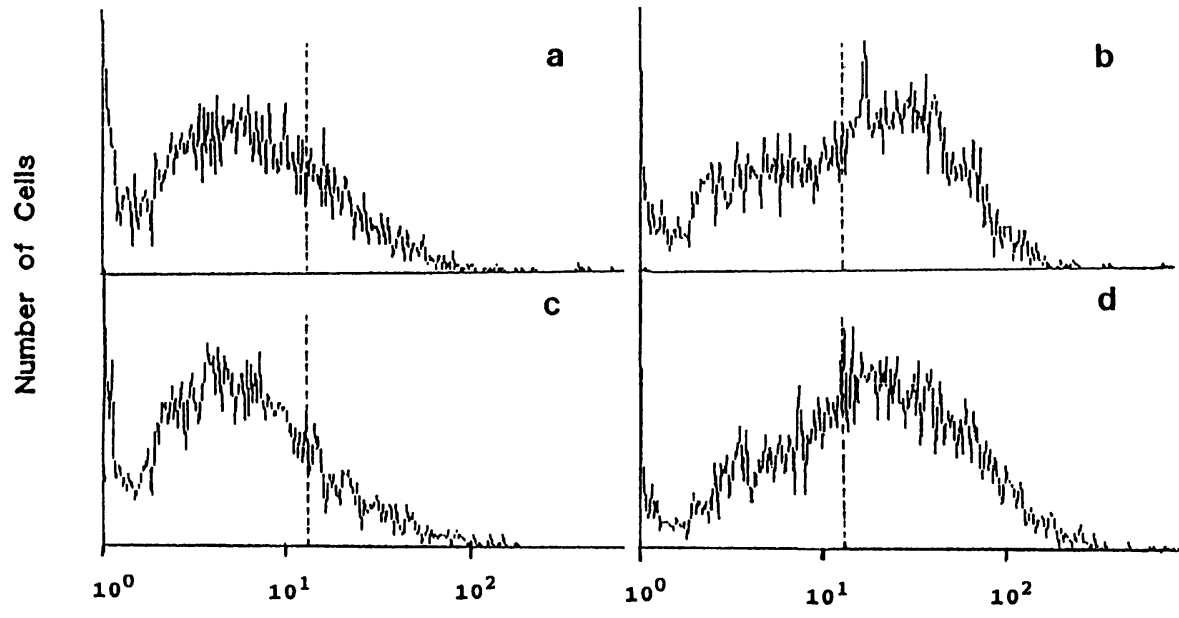

Figure 2. Flow cytometry of small cell lung cancer cells with fluorescent phospholipid vesicles. A heterogenous population of small cell lung cancer cells was incubated with fluorescent phospholipid vesicles which either did not ( $a$ ) or did contain purified P-selectin $(b-d)$. A shift in the log fluorescent intensity was seen when the small cell lung cancer cells were incubated with P-selectin containing phospholipid vesicles $(b)$. This shift due to binding of the vesicles to small cell lung cancer cells was abolished by preincubation of the Pselectin containing vesicles with the inhibitory anti-P-selectin antibody, GA6 (c), and was not abolished with BR5, an antibody to von Willebrand factor propolypeptide $(d)$. We have also done the assay with the noninhibitory antibody to P-selectin,

Log Fluorescent Intensity $\mathrm{ACl}$.2, which either showed no inhibition or partial inhibition depending on the day of the experiment. Fluorescence intensity is given on the $x$ axis and cell number is given on the $y$ axis. 5,000 cells were counted.

intensity that was inhibited with the inhibitory antibody to P-selectin. No such shift in fluorescent intensity was seen with the negative control, Daudi cells (not shown). The neuroblastoma cell line, SK-N-SH, also bound to the P-selectin-containing phospholipid vesicles compared with the phospholipid vesicles alone ( see the control cells in Table III). This shift in the fluorescent intensity was inhibited when the assay was done in the presence of an inhibitory antibody to P-selectin (data not shown) and no significant inhibition of binding occurred when the assay was performed in the presence of an noninhibitory, anti-P-selectin antibody, AC1.2 (data not shown).

Further characterization of the carbohydrate ligand on the cancer cells. Using flow cytometry, we examined if fluorescent phospholipid vesicles containing purified P-selectin bound to the neuroblastoma cell line, SK-N-SH, when treated with inhibitors of the biosynthesis and processing of $\mathrm{N}$-linked oligosaccharide chains (Table III). The cells were grown in the presence of tunicamycin $(0.1 \mu \mathrm{g} / \mathrm{ml}$ and $1.0 \mu \mathrm{g} / \mathrm{ml})$, an antibiotic that inhibits $\mathrm{N}$-linked glycosylation as well as inhibits $10-60 \%$ of protein synthesis at these concentrations (42). In parallel, the tunicamycin $(1.0 \mu \mathrm{g} / \mathrm{ml})$ was used to inhibit N-linked glycosylation in endothelial cells to test its activity. Only at the higher

Table II. Rosetting Assay of Activated Platelets from a Normal Donor and a Patient with Glanzmann's Thrombasthenia with HL60 and Small Cell Lung Cancer Cells (NCI-H128)

\begin{tabular}{|c|c|c|c|c|}
\hline & \multicolumn{4}{|c|}{ Percent adherence* } \\
\hline & \multicolumn{2}{|c|}{$\begin{array}{l}\text { Normal donor } \\
\text { platelets }\end{array}$} & \multicolumn{2}{|c|}{$\begin{array}{l}\text { Glanzmann's thrombasthenia } \\
\text { platelets }\end{array}$} \\
\hline & Activated & $\begin{array}{l}\text { Activated and } \\
\text { anti-P-selectin } \\
\text { antibody, GA6 }\end{array}$ & Activated & $\begin{array}{l}\text { Activated and } \\
\text { anti-P-selectin } \\
\text { antibody, GA6 }\end{array}$ \\
\hline HL60 & $82.0 \pm 6.2$ & $7.7 \pm 2.5$ & $85.0 \pm 2.0$ & $4.0 \pm 1.4$ \\
\hline NCI-H 128 & $77.0 \pm 6.2$ & $13.0 \pm 6.5$ & $78.0 \pm 5.6$ & $13.0 \pm 1.0$ \\
\hline
\end{tabular}

* Mean percentage of cells with two or more platelets bound plus standard deviation. concentration, tunicamycin partially inhibited the binding of the P-selectin-containing phospholipid vesicles to the SK-NSH cells (Table III). Growth of these cells in the presence of deoxymannojirimycin $(100 \mu \mathrm{g} / \mathrm{ml})$ which inhibits mannosidase 1A/B (43) and swainsonine $(1 \mu \mathrm{g} / \mathrm{ml})$ which inhibits mannosidase II (44), had no effect on the binding of the P-selectin-containing phospholipid vesicles ( Table III). These data indicate that the carbohydrate ligand on this neuroblastoma cell line is not $\mathrm{N}$-linked to the protein core.

Since P-selectin is known to bind to carbohydrate structures containing the sialyl-Lewis $X$ antigen (26-28), we wanted to see if the tumor cell lines that bound to P-selectin were recognized by antibodies to this and related determinants. We evaluated by immunofluorescence and flow cytometry the expression of Lewis $\mathrm{X}$ antigen and sialyl-Lewis $\mathrm{X}$ antigen with the binding of monoclonal antibodies CD15 and CSLEX1, respectively. All cell lines which bound to P-selectin on activated platelets expressed the Lewis X antigen (Table IV). However, only the promyelocytic cell line, HL60, and the colon carcinoma cell line, HT-29, which does not bind to P-selectin, expressed the sialyl-Lewis $\mathrm{X}$ antigen ( Table IV). Immunofluores-

Table III. Flow Cytometry of Neuroblastoma Cell Line, SK-NSH, Growth in the Presence of Carbohydrate Synthesis Inhibitors and then Incubated with Fluorescent Phospholipid Vesicles

\begin{tabular}{lcc}
\hline & \multicolumn{2}{c}{ Specific linear fluorescent intensity } \\
\cline { 2 - 3 } & Phospholipid alone & $\begin{array}{c}\text { Phospholipid with } \\
\text { P-selectin }\end{array}$ \\
\hline $\begin{array}{l}\text { Control } \\
\text { Tunicamycin } \\
0.1 \mu \mathrm{g} / \mathrm{ml} \times 30 \mathrm{~h}\end{array}$ & 4.9 & 22.1 \\
$\begin{array}{c}\text { Tunicamycin } \\
1.0 \mu \mathrm{g} / \mathrm{ml} \times 30 \mathrm{~h}\end{array}$ & 4.6 & 18.3 \\
$\begin{array}{c}\text { Deoxymannojirimycin } \\
100 \mu \mathrm{g} / \mathrm{ml} \times 30 \mathrm{~h}\end{array}$ & 4.3 & 11.9 \\
$\begin{array}{c}\text { Swainsonine } \\
1 \mu \mathrm{g} / \mathrm{ml} \times 30 \mathrm{~h}\end{array}$ & 4.9 & 20.8 \\
\hline
\end{tabular}



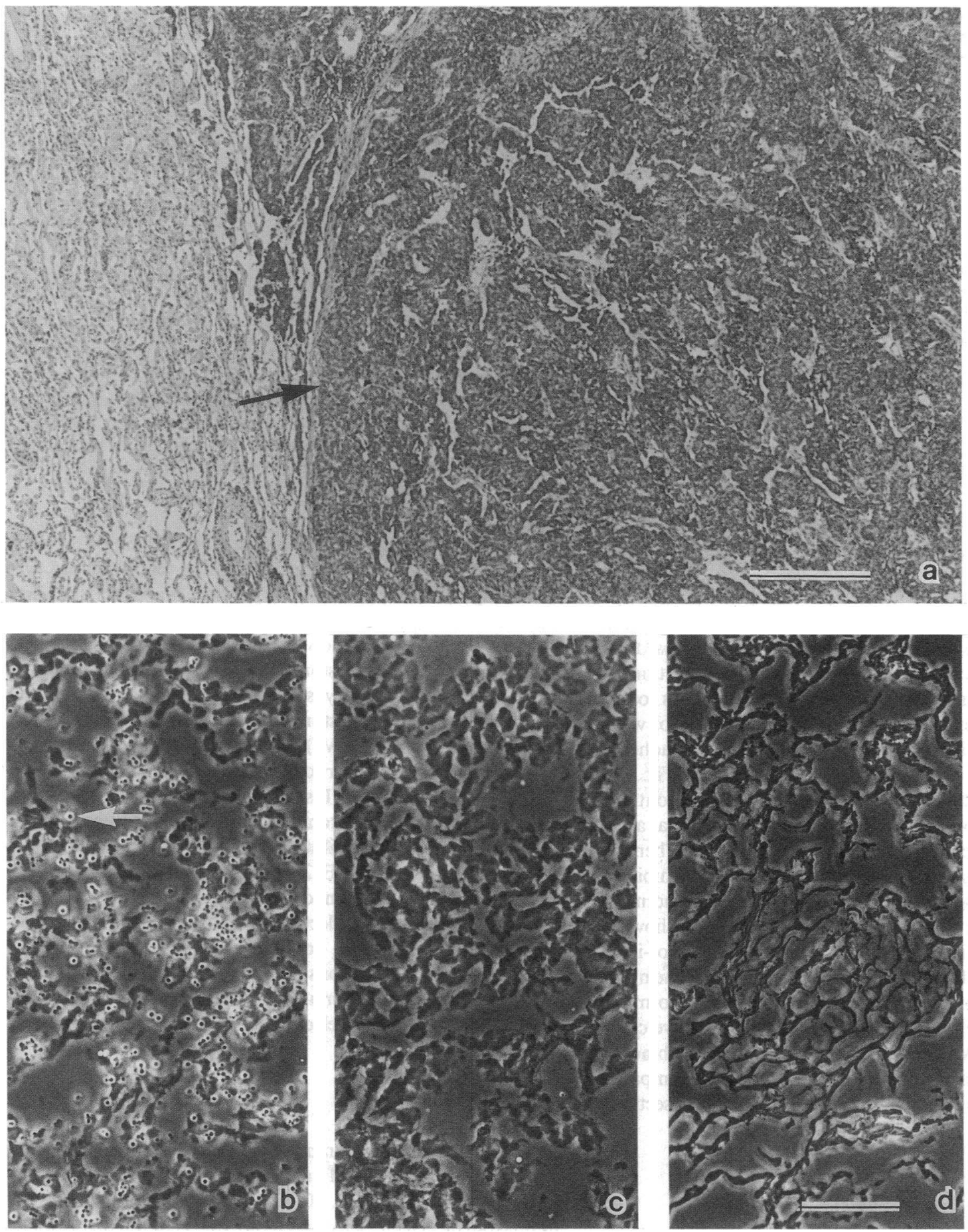

Figure 3. Cryostat sections of small cell lung cancer. An intermediate grade small cell lung carcinoma was excised from a patient's lung. Cryostat sections obtained from the same block of this tumor were studied: $(a)$ Hematoxylin and eosin stain demonstrating a monotonous infiltrate of small cell lung carcinoma cells. The arrow points to the edge of the tumor which stains darker. The surrounding lung tissue is seen to the left of the arrow. Bar $=300 \mu \mathrm{m}$. (b) Lipospheres containing P-selectin bound to these tumor cells. The arrow points to one of them. $(c)$ Rare lipospheres without P-selectin bound to an adjacent section of the small cell lung carcinoma. $(d)$ Very few lipospheres containing P-selectin bound to an area of lung tissue which was not infiltrated with small cell lung carcinoma. Bar $=30 \mu \mathrm{m}$ for $b-d$.

cent staining observations of the tumor cells gave similar results, showing heterogeneity of antigen expression between individual cells (not shown).

Binding of P-selectin lipospheres to frozen sections of human tumors. To evaluate if P-selectin expressed either on activated platelets or stimulated endothelium binds to small cell lung carcinoma or to neuroblastoma in primary tissue samples and not just to cultured tumor cell lines, we have adapted for our purposes the Stamper and Woodruff assay (39) developed to study lymphocyte adhesion to high endothelium of peripheral lymph nodes. First, a small cell lung carcinoma excised from a human lung was used to make cryostat sections for this 
Table IV. Immunoreactivity of Cancer Cell Lines with Antibodies to Carbohydrate Antigens

\begin{tabular}{|c|c|c|c|c|}
\hline \multirow[b]{2}{*}{ Cell type } & \multicolumn{4}{|c|}{ Specific linear fluorescent intensity } \\
\hline & $\begin{array}{l}\text { Binding to } \\
\text { activated } \\
\text { platelets' } \\
\text { P-selectin }\end{array}$ & $\begin{array}{l}\text { FACS } \\
\text { buffer }\end{array}$ & Anti-CD15 & Anti-CSLEX 1 \\
\hline Daudi & - & 3.5 & 2.6 & 3.1 \\
\hline HL60 & + & 2.5 & 305.0 & 527.0 \\
\hline $\begin{array}{l}\text { NCI-H128 } \\
\quad \text { (Small cell lung cancer) }\end{array}$ & + & 2.8 & 105.0 & 2.9 \\
\hline $\begin{array}{l}\text { NCI-H345 } \\
\quad \text { (Small cell lung cancer) }\end{array}$ & + & 3.7 & 48.4 & 4.9 \\
\hline $\begin{array}{l}\text { hHB5-A2 } \\
\text { (Neuroblastoma) }\end{array}$ & + & 5.7 & 17.6 & 5.6 \\
\hline $\begin{array}{l}\text { SK-N-SH } \\
\quad \text { (Neuroblastoma) }\end{array}$ & + & 2.3 & 21.0 & 3.1 \\
\hline CRL 1566 (Teratocarcinoma) & + & 3.2 & 135.6 & 4.7 \\
\hline HT-29 (Colon) & - & 5.1 & 8.9 & 28.7 \\
\hline
\end{tabular}

Cell lines are as in Table I.

assay. Hematoxylin and eosin stains of the cryostat sections showed that the areas of the section studied were composed of a uniform infiltrate of cancer cells (Fig. $3 a$ ). Cryostat sections of the small cell lung tumor were overlaid with glass beads coated with a bilayer of fluorescent phospholipid either with or without P-selectin. The lipospheres containing P-selectin adhered avidly to tumor cells present in the cryostat sections (Fig. $3 b$ ) and not to areas of normal lung tissue (Fig. $3 d$ ). In contrast, the lipospheres without P-selectin did not bind to similar areas of tumor on the adjacent cryostat sections (Fig. $3 c$ ). When the lipospheres with P-selectin were incubated with inhibitory monoclonal or polyclonal antibodies to P-selectin, binding of these beads to the cryostat sections was inhibited (not shown).

The extent to which lipospheres bound to the tumor-infiltrated areas on the different cryostat sections varied. The number of lipospheres bound in an area composed of uniform tumor infiltrate was determined in a series of consecutive cryostat sections (Table V). A greater than 10-fold higher binding was noted with P-selectin containing lipospheres as compared to lipospheres lacking P-selectin. When the cryostat sections

Table V. Binding of P-selectin-containing Lipospheres to Cryostat Sections of Small Cell Lung Carcinoma Excised from a Human Lung

\begin{tabular}{lrc}
\hline & $\begin{array}{c}\text { Number of lipospheres bound } \\
\text { per } 0.33 \mathrm{~mm}^{2 *} \text { of section }\end{array}$ \\
\hline $\begin{array}{l}\text { Phospholipid only } \\
\text { P-selectin incorporated in phospholipid }\end{array}$ & 41 & 89 \\
$\begin{array}{l}\text { P-selectin sections pretreated with } \\
\text { neuraminidase }\end{array}$ & 640 & 1714 \\
& 130 & 135
\end{tabular}

* Number of lipospheres bound to seven fields (total surface 0.33 $\mathrm{mm}^{2}$ ) of a cryostat section was determined using the $\times 40$ lens on an MC 100 Zeiss microscope. All cryostat sections were made sequentially from the same tumor block, for each variable two sections were evaluated.
Table VI. Liposphere Binding to Cryostat Sections of a Neuroblastoma Tumor Excised from an Adrenal Gland

\begin{tabular}{lrrrr}
\hline & $\begin{array}{r}\text { Number of lipospheres bound } \\
\text { per } 1.89\end{array}$ & $\mathrm{~mm}^{2 *}$ of section \\
\hline Phospholipid only & 16 & 21 & 14 & 62 \\
$\begin{array}{l}\text { P-selectin incorporated in phospholipid } \\
\text { P-selectin + inhibitory monoclonal to }\end{array}$ & 155 & 158 & 574 & 378 \\
$\quad$ & 17 & 33 & & \\
$\begin{array}{l}\text { P-selectin } \\
\text { P-selectin + EDTA }\end{array}$ & 21 & 46 & \\
$\begin{array}{l}\text { P-selectin sections pretreated with } \\
\text { neuraminidase }\end{array}$ & 90 & 94 & \\
& & & & \\
\hline
\end{tabular}

* Average number of lipospheres bound to 10 fields (total surface 1.89 $\mathrm{mm}^{2}$ ) of a cryostat section was determined using the $\times 40$ lens of a BH-2 microscope. The inhibitory monclonal was GE12. EDTA was used at $10-\mathrm{mM}$ concentration. All cryostat sections were made sequentially from the same tumor block, for each variable two to four sections were evaluated.

were pretreated with neuraminidase, the binding of the glass beads coated with P-selectin containing phospholipid was markedly decreased (Table V). Therefore it appears that similar to the cultured small cell lung cancer cells, the tumor interaction with P-selectin involves a sialic acid-containing ligand.

In addition, neuroblastoma tumors and other lung tumors were evaluated in this cryostat assay. Equivalent results were obtained with a neuroblastoma tumor excised from an adrenal gland of a patient ( Table VI) and from a neuroblastoma tumor excised from the retroperitoneum of a different patient (not shown). The binding of P-selectin-containing lipospheres to sections of the neuroblastoma tumor excised from an adrenal gland was completely inhibited with an inhibitory monoclonal antibody to P-selectin, GE12, or with EDTA (Table VI). Also in this tumor, pretreatment of the sections with neuraminidase significantly reduced P-selectin-mediated binding (Table VI). Not all tumors, however, bound the P-selectin-containing lipospheres. Neither sections of a poorly differentiated squamous cell lung cancer nor a well differentiated squamous cell lung cancer bound P-selectin-containing lipospheres (not shown).

\section{Discussion}

P-selectin is a transmembrane adhesion receptor that is rapidly expressed on platelet and endothelial cell plasma membrane during vascular injury $(9,10,45)$. Since it mediates adhesion to phagocytic cells, P-selectin's likely role is in the recruitment of the phagocytic cells to the injured area, where they are needed as defense against infection and to remove debris during the process of wound healing. P-selectin expressed on surrounding endothelial cells may be important for the initial stages of leukocyte extravasation. Since the carbohydrate component of the P-selectin ligand may be expressed on tumor cells $(31,32)$, we investigated if P-selectin mediates binding to tumor cells.

Our study demonstrates that activated platelets bind to small cell lung cancer cells, neuroblastoma cells, and teratocarcinoma cells and that the binding is mediated by P-selectin. This conclusion was based on the following observations: polyclonal and inhibitory monoclonal antibodies to P-selectin fully 
inhibited platelet adhesion to the cancer cells; preincubation of the cancer cells with purified P-selectin was also fully inhibitory; and finally, polysaccharides, fucoidin, and heparin, known to interfere with P-selectin binding to phagocytic cells (41), also prevented platelet binding to the small cell lung cancer cells (Fig. 1). P-selectin alone was sufficient to promote binding to the cancer cells as demonstrated by specific binding of phospholipid vesicles containing purified P-selectin to the small cell lung cancer cells and neuroblastoma cells in culture and in tissue sections (Figs. 2 and 3, and Tables III, V, and VI).

Platelets have been reported to bind to certain tumor cells such as human cervical carcinoma (MS751) cells and HM29 melanoma through the integrin receptor GP IIb-IIIa on the platelet surface $(6,8)$. The tumor cells that interact with platelets in .. GP IIb-IIIa-dependent manner may actually themselves express an authentic GP IIb-IIIa complex (46) and their interaction with platelets may therefore be mechanistically very similar to that of platelet aggregation. We have demonstrated by several criteria that GP IIb-IIIa was not involved in binding of platelets to the small cell lung cancer cells: antibody to GP IIb-IIIa, tested to be inhibitory in a platelet aggregation assay, did not inhibit rosetting of platelets with the small cell lung cancer cells, nor did the RGDS peptide have a significant effect in this assay (Fig. $1 A$ ). In addition, platelets from a patient with Glanzmann's thrombasthenia that lack functional GP IIb-IIIa bound extensively to both the small cell lung cancer cells and to the control HL60 cells ( Table II ). It appears therefore that platelets may interact with cancer cells by two independent mechanisms depending on the surface properties of the specific cancer cell type. One mechanism involves integrin receptors on both cells and likely requires a soluble ligand: the other mechanism involves P-selectin on the activated platelet and a glycoprotein ligand on the tumor cell.

Among the human cancer cell lines tested ( Table I), several did not bind significantly to platelets in the rosetting assay. One was the human colon carcinoma HT-29 that was previously shown by Rice and Bevilacqua (34) to bind to E-selectin on activated endothelial cells. Indeed, when we tested these HT-29 cells for binding to Chinese hamster ovary cells transfected with either P-selectin or E-selectin (generously provided by Drs. D. Sako and G. Larsen, Genetics Institute, Cambridge, MA) they bound to the E-selectin but not to the P-selectin-expressing cells. This observation provides further evidence that despite their similarities the ligands for $\mathrm{P}$ - and E-selectin are not identical (30).

The ligand for P-selectin on monocytes and neutrophils is a glycoprotein (s). The same appears to be the case for the small cell lung cancer cell and the neuroblastoma cell ligand. Treatment of these cultured cancer cells with trypsin or neuraminidase (Fig. 1) and treatment of tissue sections with neuraminidase (Tables V and VI) completely abolished P-selectin-mediated binding. This result is in contrast to a recent publication by Aruffo and colleagues (47). The authors studied the interaction of a soluble immunoglobulin chimera of P-selectin with cancer cells and tumor sections and found that chimera binding was not dependent on the presence of sialic acid and was only variably diminished by protease treatment. The authors proposed that the chimera bound predominantly to sulfatides, in agreement with the observation that the strongest binding in tissue sections was intracellular where sulfatides are the most abundant. Aruffo and colleagues (47) have observed binding of the immunoglobulin chimera of P-selectin to all tumor cells in all carcinomas they examined (breast, colon, and lung). This is a further indication that the chimera was indeed binding to sulfatides which are ubiquitous. The identical soluble chimera was used earlier to demonstrate binding of P-selectin to sulfatides on myeloid cells (48). It subsequently has become evident that sulfatides are not involved in the physiological interaction of the myeloid cells with platelets. Several groups have shown that platelet binding is fully inhibited by protease or neuraminidase treatment of the myeloid cells $(29,30,49)$. In addition, activated platelets that express both sulfatides ( 50$)$ and P-selectin should aggregate if the sulfatides could serve as P-selectin ligand. This is not the case $(9,10)$; platelets do not aggregate in the absence of a soluble ligand such as fibrinogen or von Willebrand factor. It is possible that the soluble P-selectin chimera can achieve closer proximity to the plasma membrane than the P-selectin molecule anchored in a platelet. Therefore, although a soluble form of P-selectin may bind to sulfatides of many cell types, it is unlikely to do so when expressed on the plasma membrane of an activated platelet. The use of platelets and endothelial cells to study the molecules involved in their binding to tumor cells appears to be, at least initially, the most direct approach.

Carbohydrates expressed on tumor cells appear to play a role in metastasis (51-53). For example, a disaccharide nucleoside, which has inhibitory activity against sialyl transferase, causes inhibition of experimental pulmonary metastasis of a murine colon adenocarcinoma when cells are treated with the inhibitor before injection. The inhibitor-treated adenocarcinoma cells also have a reduced ability to induce platelet aggregation in vitro (54).

We have demonstrated in this study that a sialic acid-containing carbohydrate on a protein backbone serves as ligand on small cell lung cancer cells and neuroblastoma cells for P-selectin on activated platelets. In addition, our results obtained with the neuroblastoma cells grown in the presence of inhibitors of the biosynthesis or processing of $\mathrm{N}$-linked oligosaccharide chains, indicate that the ligand on these cancer cells is an $\mathrm{O}$ linked oligosaccharide. The P-selectin ligand on the myelocytic cell lines HL60 and U937 was recently also shown to be an O-linked carbohydrate $(55,56)$. The exact carbohydrate structure present on the cancer cells that directs binding to P-selectin is not known. In contrast to neutrophils and monocytes, all the tumor cells that bound P-selectin in this study were negative for sialyl-Lewis X (Table IV). This indicates that either sialyl-Lewis $\mathrm{X}$ is not present on the cancer cells or that its conformation is different and is not recognized by the CSLEX 1 antibody. The sialic acid that is crucial for the P-selectin-mediated binding of platelets to the cancer cells (Fig. 1) may therefore be a part of carbohydrate structure distinct from sialylLewis X. Oncogenic transformation leads both to more carbohydrate branches per core and to a higher sialylation of the asparagine-linked complex carbohydrate (57-59). Transformation therefore causes induction of glycosyl transferases, and this process is likely to occur also in vivo. Expression of a specific fucosyl or sialyl transferase may result in the formation of the P-selectin ligand. It is also possible that induction of the protein backbone determines the existence of the P-selectin ligand, since the ligand specificity may include the protein core.

The ligand on cancer cells for platelet P-selectin is likely also recognized by P-selectin expressed on endothelial cells. In the endothelial cells, P-selectin is stored in organelles called 
Weibel-Palade bodies $(24,25)$ that are the storage granules for von Willebrand factor (60). Many agents generated during vascular injury and inflammation cause rapid release of von Willebrand factor from Weibel-Palade bodies. Simultaneously P-selectin is translocated to the cell surface where it can serve as an adhesion receptor (21). The known secretagogues are: thrombin (61), fibrin (62), histamine (63), and complement components C5b9 (45). Interestingly, vascular permeability factor, a protein secreted by many cancer cells (64), was recently shown to stimulate release of Weibel-Palade bodies (65). Therefore, similar to the known activation of platelets by cancer cells (4), cancer cells may also stimulate granule release from endothelial cells. This would result in their increased adherence to the vessel wall through the expression of P-selectin. Some cancer treatments may cause vascular injury resulting in the appearance of P-selectin on the surface of blood vessels and capillaries. This in turn may increase the probability of successful metastases. For example, irradiation was shown by Sporn and colleagues (66) to cause release of Weibel-Palade bodies from endothelial cells in culture 1-2 d after irradiation. Although some cancer cells may be recognized by both $\mathrm{P}$ - and E-selectin, the circumstances under which the two proteins are expressed on the endothelial plasma membrane are very different. Studies on their expression patterns will help to determine the relative importance of these two selectins in the metastatic process.

P-selectin may play several roles in the early events of hematogenous metastasis. Its presence on endothelial cells may promote the initial attachment of the cancer cells to the vessel wall. P-selectin on activated platelets may in turn guide their recruitment to the arrested cancer emboli providing protection, growth factors and added stability. Morphological observations show that in most instances platelets surround the cancer cells until invasion of the basement membrane occurs (67). The demonstrated interaction of cancer cells with P-selectin is yet another example of a molecular mechanism used in wound healing or inflammation which may be adapted by the tumor to enhance metastasis.

\section{Acknowledgments}

The authors thank Drs. Jean Paul Thiery, Bruce Furie, and Barbara Furie for helpful discussions, and Drs. Ina Bhan, Joseph Alroy, Stephen Naber, and James Mueller for their help with the studies of cryostat sections. We also very much appreciate Dr. Gary Gilbert's help with liposphere preparation, and Drs. Bruce and Barbara Furie for providing inhibitory monoclonal antibodies to P-selectin. The authors are grateful to Dr. Murray Burn for identifying the patient with Glanzmann's thrombasthenia, and Dr. John Erban for fully characterizing the patient's platelets.

This work was supported by a grant (Pol HL-42443) from the National Institutes of Health. J.P. Stone is the recipient of National Research Award (HL-08525) from the National Institutes of Health.

\section{References}

1. Karpatkin, S., and E. Pearlstein. 1981. Role of platelets in tumor cell metastases. Ann. Intern. Med. 95:636-641.

2. Gasic, G. J., G. P. Tuszynski, and E. Gorelik. 1986. Interaction of the hemostatic and immune systems in the metastatic spread of tumor cells. Int. Rev. Exp. Pathol. 29:173-212.

3. Bastida, E., and A. Ordinas. 1988. Platelet contribution to the formation of metastatic foci: the role of cancer cell-induced platelet activation. Haemostasis. 18:29-36.

4. Honn, K. V., I. M. Grossi, J. Timar, H. Chopra, and J. D. Taylor. 1991. Platelets and cancer metastasis. In Microcirculation and Cancer Metastasis. M.
Weiss, M. Buchanan, and F. W. Orr, editors. CRC Press/London-Oxford. 93110.

5. Gasic, G., T. Gasic, and C. Stewart. 1968. Antimetastatic effects associated with platelet reduction. Proc. Natl. Acad. Sci. USA. 61:46-52.

6. Grossi, I. M., L. A. Fitzgerald, A. Kendall, J. D. Taylor, B. F. Sloane, and K. V. Honn. 1987. Inhibition of human tumor cell induced platelet aggregation by antibodies to platelet glycoproteins Ib and IIb/IIIa. Proc. Soc. Exp. Biol. Med. 186:378-383.

7. Karpatkin, S., E. Pearlstein, C. Ambrogio, and B. S. Coller. 1988. Role of adhesive proteins in platelet tumor interaction in vitro and metastasis formation in vivo. J. Clin. Invest. 81:1012-1019.

8. Nierodzik, M. L., A. Plotkin, F. Kajumo, and S. Karpatkin. 1991. Thrombin stimulates tumor-platelet adhesion in vitro and metastasis in vivo. J. Clin Invest. 87:229-236.

9. Hsu-Lin, S. C., C. L. Berman, B. C. Furie, D. August, and B. Furie. 1984. A platelet membrane protein expressed during platelet activation. J. Biol. Chem. 259:9121-9126.

10. McEver, R. P., and M. N. Martin. 1984. A monoclonal antibody to a membrane glycoprotein binds only to activated platelets. J. Biol. Chem. 259:9799-9804.

11. Springer, T. A. 1990. Adhesion receptors of the immune system. Nature (Lond.). 346:425-434.

12. Gallatin, W. M., I. L. Weissman, and E. C. Butcher. 1983. A cell-surface molecule involved in organ-specific homing of lymphocytes. Nature (Lond.). 304:30-34.

13. Bevilacqua, M. P., J. S. Pober, D. L. Mendrick, R. S. Cotran, and M. A. Gimbrone, Jr. 1987. Identification of an inducible endothelial-leukocyte adhesion molecule, ELAM-1. Proc. Natl. Acad. Sci. USA. 84:9238-9242.

14. Siegelman, M. H., and I. L. Weissman. 1989. Human homologue of mouse lymph node homing receptor: evolutionary conservation at tandem cell interaction domains. Proc. Natl. Acad. Sci. USA. 86:5562-5566.

15. Lasky, L. A., M. S. Singer, T. A. Yednock, D. Dowbenko, C. Fennie, H. Rodriguez, T. Nguyen, S. Stachel, and S. D. Rosen. 1989. Cloning of a lymphocyte homing receptor reveals a lectin domain. Cell. 56:1045-1055.

16. Tedder, T. F., C. M. Isaacs, T. J. Ernst, G. D. Demetri, D. A. Adler, and C. M. Disteche. 1989. Isolation and chromosomal localization of cDNAs encoding a novel human lymphocyte cell surface molecule, LAM-1. Homology with the mouse lymphocyte homing receptor and other human adhesion proteins. $J$. Exp. Med. 170:123-133.

17. Bevilacqua, M. P., S. Stengelin, M. A. Gimbrone, Jr., and B. Seed. 1989. Endothelial leukocyte adhesion molecule 1: an inducible receptor for neutrophils related to complement regulatory proteins and lectins. Science (Wash. DC). 243:1160-1165.

18. Johnston, G. I., R. G. Cook, and R. P. McEver. 1989. Cloning of GMP140 , a granule membrane protein of platelets and endothelium: sequence similarity to proteins involved in cell adhesion and inflammation. Cell. 56:1033-1044.

19. Larsen, E., A. Celi, G. E. Gilbert, B. C. Furie, J. K. Erban, R. Bonfanti, D. D. Wagner, and B. Furie. 1989. PADGEM protein: a receptor that mediates the interaction of activated platelets with neutrophils and monocytes. Cell. 59:305-312.

20. Hamburger, S. A., and R. P. McEver. 1990. GMP-140 mediates adhesion of stimulated platelets to neutrophils. Blood. 75:550-554.

21. Geng, J.-G., M. P. Bevilacqua, K. L. Moore, T. M. McIntyre, S. M. Prescott, J. M. Kim, G. A. Bliss, G. A. Zimmerman, and R. P. McEver. 1990. Rapid neutrophil adhesion to activated endothelium mediated by GMP-140. Nature (Lond.). 343:757-760.

22. Stenberg, P. E., R. P. McEver, M. A. Shuman, Y. V. Jacques, and D. F. Bainton. 1985. A platelet alpha-granule membrane protein (GMP140) is expressed on the plasma membrane after activation. J. Cell Biol. 101:880-886.

23. Berman, C. L., E. L. Yeo, J. Wencel-Drake, B. C. Furie, M. L. Ginsberg, and B. Furie. 1986. A platelet alpha granule membrane protein that is associated with the plasma membrane after activation: characterization and subcellular localization of platelet activation-dependent granule-external membrane protein. J. Clin. Invest. 78:130-137.

24. Bonfanti, R., B. C. Furie, B. Furie, and D. D. Wagner. 1989. PADGEM (GMP-140) is a component of Weibel-Palade bodies of human endothelial cells. Blood. 73:1109-1112.

25. McEver, R. P., J. H. Beckstead, K. L. Moore, L. Marshall-Carlson, and D. F. Bainton. 1989. GMP-140, a platelet alpha-granule membrane protein, is also synthesized by vascular endothelial cells and is localized in Weibel-Palade bodies. J. Clin. Invest. 84:92-99.

26. Larsen, E., T. Palabrica, S. Sajer, G. E. Gilbert, D. D. Wagner, B. C. Furie, and B. Furie. 1990. PADGEM-dependent adhesion of platelets to monocytes and neutrophils is mediated by a lineage-specific carbohydrate, LNF III (CD15). Cell. 63:467-474.

27. Polley, M. J., M. L. Phillips, E. Wayner, E. Nudelman, A. K. Singhal, S. Hakomori, and J. C. Paulson. 1991. CD62 and endothelial cell-leukocyte adhesion molecule 1 (ELAM-1) recognize the same carbohydrate ligand, sialyl-Lewis x. Proc. Natl. Acad. Sci. USA. 88:6224-6228.

28. Zhou, Q., K. L. Moore, D. Smith, A. Varki, R. P. McEver, and R. D. 
Cummings. 1991. The selectin GMP-140 binds to sialyated, fucosylated lactosaminoglycans on both myeloid and nonmyeloid cells. J. Cell Biol. 115:557-564.

29. Moore, K. L., A. Varki, and R. P. McEver. 1991. GMP-140 binds to a glycoprotein receptor on human neutrophils: evidence for a lectin-like interaction. J. Cell Biol. 112:491-499.

30. Larsen, G., D. Sako, T. Ahern, M. Shaffer, J. Erban, S. A. Sajer, R. M. Gibson, D. D. Wagner, B. C. Furie, and B. Furie. 1992. P-selectin and E-selectin: distinct but overlapping leukocyte ligand specificities. J. Biol. Chem. 267:1110411110.

31. Magnani, J. L., B. Nilsson, M. Brockhaus, D. Zopf, Z. Steplewski, H. Koprowski, and V. Ginsburg. 1982. A monoclonal antibody-defined antigen associated with gastrointestinal cancer is a ganglioside containing sialylated lactoN-fucopentaose II. J. Biol. Chem. 23:14365-14369.

32. Fukushima, K., M. Hirota, P. Terasaki, A. Wakisaka, H. Togashi, D. Chia, N. Suyama, Y. Fukushi, E. Nudelman, and S. Hakomori. 1984. Characterization of sialosylated Lewis ${ }^{\mathrm{x}}$ as a new tumor-associated antigen. Cancer Res. 44:5279-5285.

33. Yousefi, S., E. Higgins, Z. Daoling, A. Pollex-Kruger, O. Hindsgaul, and J. W. Dennis. 1991. Increased UDP-GlcNAc:Gal $\beta 1-3 G a l N A c-R(G l c N A c$ to GalNAc) $\beta-1,6-N$-Acetylglucosaminyltransferase activity in metastatic murine tumor cell lines. J. Biol. Chem. 266:1772-1782.

34. Rice, E. G., and M. P. Bevilacqua. 1989. An inducible endothelial cell surface glycoprotein mediates melanoma adhesion. Science (Wash. DC). 246:1303-1306.

35. Hession, C., L. Osborn, D. Goff, G. Chi-Rosso, C. Vassallo, M. Pasek, C. Pittack, R. Tizard, S. Goelz, K. McCarthy, S. Hopple, and R. Lobb. 1990. Endothelial leukkocyte adhesion molecule 1: direct expression cloning and functional interactions. Proc. Natl. Acad. Sci. USA. 87:1673-1677.

36. Palabrica, T., R. Lobb, B. C. Furie, M. Aronowitz, C. Benjamin, Y. M. Hsu, S. Sajer, and B. Furie. 1992. Leukocyte accumulation promoting fibrin deposition is mediated in vivo by P-selectin on adherent platelets. Nature (Lond.). 359:848-851.

37. Wagner, D. D., S. O. Lawrence, B. M. Ohlsson-Wilhelm, P. J. Fay, and V. J. Marder. 1987. Topology and order of formation of interchain disulfide bonds in von Willebrand factor. Blood. 69:27-32.

38. Gilbert, G. E., D. Drinkwater, S. Barter, and S. B. Clause. 1992. Specificity of phosphatidylserine-containing membrane binding sites for factor VIII. Studies with model membranes supported by glass microspheres (lipospheres). J. Biol. Chem. 267:15861-15868.

39. Stamper, H. B., and J. J. Woodruff. 1976. Lymphocyte homing into lymph nodes: in vitro demonstration of the selective affinity of recirculating lymphocytes for high endothelial venules. J. Exp. Med. 144:828-833.

40. Stoolman, M. L., and S. D. Rosen. 1983. Possible role for cell-surface carbohydrate-binding molecules in lymphocyte recirculation. J. Cell Biol. 96:722-729.

41. Skinner, M. P., C. M. Lucas, G. F. Burns, C. N. Chesterman, and M. C. Berndt. 1991. GMP-140 binding to neutrophils is inhibited by sulfated glycans. $J$. Biol. Chem. 266:5371-5374.

42. Struck, D. K., and W. J. Lennarz. 1977. Evidence for the participation of saccharide-lipids in the synthesis of the oligosaccharide chain of ovalbulmin. $J$. Biol. Chem. 252:1007-1013.

43. Fuhrmann, U., E. Bause, G. Legler, and H. Ploegh. 1984. Novel mannosidase inhibitor blocking conversion of high mannose to complex oligosaccharides. Nature (Lond.). 307:755-758.

44. Tulsiani, D. R. P., M. Harris, and O. Touster. 1982. Swainsonine inhibits the biosynthesis of complex glycoproteins by inhibition of Golgi mannosidase II J. Biol. Chem. 257:7936-7939.

45. Hattori, R., K. K. Hamilton, R. P. McEver, and P. J. Sims. 1989. Complement proteins C5b-9 induce secretion of high molecular weight multimers of endothelial von Willebrand factor and translocation of granule membrane protein GMP-140 to the cell surface. J. Biol. Chem. 264:9053-9060.

46. Chang, S. Y., Y. Q. Chen, L. A. Fitzgerald, and K. V. Honn. 1991. Analysis of integrin mRNA in human and rodent tumor cells. Biochem. Biophys. Res. Commun. 176:108-113.

47. Aruffo, A., M. T. Dietsch, H. Wan, K. E. Hellstrom, and I. Hellstrom 1992. Granule membrane protein 140 (GMP140) binds to carcinomas and carcinoma-derived cell lines. Proc. Natl. Acad. Sci. USA. 89:2292-2296.
48. Aruffo, A., W. Kolanus, G. Walz, P. Freedman, and B. Seed. 1991. CD62/ P-selectin recognition of myeloid and tumor cell sulfatides. Cell. 76:35-44.

49. Corral, L., M. S. Singer, B. A. Macher, and S. D. Rosen. 1990. Requirement for sialic acid on neutrophils in a GMP-140 (PADGEM) mediated adhesive interaction with activated platelets. Biochem. Biophys. Res. Commun. 172:13491356.

50. Murakami, H., Z. Lam, B. C. Furie, V. N. Reinhold, T. Asano, and B. Furie. 1991. Sulfated glycolipids are the platelet autoantigens for human plateletbinding monoclonal anti-DNA-autoantibodies. J. Biol. Chem. 266:1541415419.

51. Humphries, M. J., K. Matsumoto, S. L. White, and K. Olden. 1986. Oligosaccharide modification by swainsonine treatment inhibits pulmonary colonization by B16-F10 murine melanoma cells. Proc. Natl. Acad. Sci. USA. 83:1752-1756.

52. Dennis, J. W., S. Laferte, C. Waghorne, M. L. Breitman, and R. S. Kerbel. 1987. $\beta 1-6$ branching of Asn-linked oligosaccharides is directly associated with metastasis. Science (Wash. DC). 236:582-585.

53. Hoff, S. D., Y. Matsushita, D. M. Ota, K. R. Cleary, T. Yamori, S. Hakomori, and T. Irimura. 1989. Increased expression of sialyl-dimeric $\mathrm{Le}^{\mathrm{x}}$ antigen in liver metastases of human colorectal carcinoma. Cancer Res. 49:6883-6888.

54. Kijima-Suda, I., T. Miyazawa, M. Itoh, S. Toyoshima, and T. Osawa. 1988. Possible mechanism of inhibition of experimental pulmonary metastasis of mouse colon adenocarcinoma 26 sublines by a sialic acid: nucleoside conjugate. Cancer Res. 48:3728-3732.

55. Kojima, N., K. Handa, W. Newman, and S. Hakomori. 1992. Inhibition of selectin-dependent tumor cell adhesion to endothelial cells and platelets by blocking O-glycosylation of these cells. Biochem. Biophys. Res. Commun. 182:1288-1295

56. Steininger, C. N., C. A. Eddy, R. M. Leimgruber, A. Mellors, and J. K. Welply. 1992. The glycoprotease of Pasteurella haemolytica A1 eliminates binding of meloid cells to P-selectin but not to E-selectin. Biochem. Biophys. Res. Commun. 188:760-766.

57. Ogata, S., T. Muramatsu, and A. Kobata. 1976. New structural characteristics of the large glycopeptides from transformed cells. Nature (Lond.). 259:580582 .

58. Wagner, D. D., R. Ivatt, A. T. Destree, and R. O. Hynes. 1981. Similarities and differences between the fibronectins of normal and transformed hamster cells. J. Biol. Chem. 256:11708-11715.

59. Hubbard, C. S. 1987. Differential effects of oncogenic transformation on $\mathrm{N}$-linked oligosaccharide processing at individual glycosylation sites of viral glycoproteins. J. Biol. Chem. 262:16403-16411.

60. Wagner, D. D., J. B. Olmstead, and V. J. Marder. 1982. Immunolocalization of von Willebrand protein in Weibel-Palade bodies of human endothelial cells. J. Cell Biol. 95:355-360.

61. Levine, J. D., J. M. Harlan, L. A. Harker, M. L. Joseph, and R. B. Counts. 1982. Thrombin-mediated release of Factor VIII antigen from human umbilical vein endothelial cells in culture. Blood. 60:531-534.

62. Ribes, J. A., C. W. Francis, and D. D. Wagner. 1987. Fibrin induces release of von Willebrand factor from endothelial cells. J. Clin. Invest. 79:117123.

63. Hamilton, K. K., and P. J. Sims. 1987. Changes in cytosolic $\mathrm{Ca}^{2+}$ associated with von Willebrand factor release in human endothelial cells exposed to histamines. Study of microcarrier cell monolayers using the fluorescent probe indo-1. J. Clin. Invest. 79:600-608.

64. Senger, D. R., S. J. Galli, A. M. Dvorak, L. A. Perruzzi, V. S. Harvey, and H. F. Dvorak. 1983. Tumor cells secrete a vascular permeability factor that promotes accumulation of ascites fluid. Science (Wash. DC). 219:983-985.

65. Brock, T. A., H. F. Dvorak, and D. R. Senger. 1991. Tumor-secreted vascular permeability factor increases cytosolic $\mathrm{Ca}^{2+}$ and von Willebrand factor release in human endothelial cells. Am. J. Pathol. 138:213-221.

66. Sporn, L. A., P. Rubin, V. J. Marder, and D. D. Wagner. 1984. Irradiation induces release of von Willebrand protein from endothelial cells in culture. Blood. 64:567-570.

67. Crissman, J. D., J. S. Hatfield, D. G. Menter, B. Sloane, and K. V. Honn. 1988. Morphological study of the interaction of intravascular tumor cells with endothelial cells and subendothelial matrix. Cancer Res. 48:4065-4072. 